"Cautiverio", último libro de poemas de Arturo Torres-Rioseco

Arturo Torres-Rioseco, el conocido poeta, crítico y profesor, acaba de publicar Cautiverio, su último libro de poemas. Poemas son éstos que dejan en el ánimo del lector una profunda impresión. Sus rimas variadas y ricas, de tendencia lírico-filosófica y múltiples facetas, combinan la expresión de profundos sentimientos interiores con la de lo que las impresiones exteriores causan en él, particularmente las de la naturaleza.

No creo que se pueda hablar de una técnica premeditada en Torres-Rioseco, pero podemos aludir a dos características principales en su poesía: La repetición (repetición de ideas y de imágenes en diferentes formas y símbolos), y las correlaciones, aunque en forma más sencilla y directa que en la de otros poetas actuales. En varios de sus poemas también podríamos hablar de paralelismo, si el poeta hubiera usado estas tres técnicas conscientemente, lo que, probablemente, no es el caso. Nos parece que es espontáneo en Torres-Rioseco que la dificilísima sencillez de sus versos sirva de envase a la dificilísima sencillez de sus ideas.

La primera parte del libro la forma una magnífica colección de sonetos, dieciocho sonetos, en los que a la absoluta perfección de la forma se une un sentir apasionado y profundo, y un claro adentrarse en lo que el autor llama (en su primer soneto) la substancia o lo esencial (los ritmos esenciales). Estos poemas, unidos por el mismo tono íntimo e iluminado, por la repetición de las mismas expresiones en claves diferentes y con palabras diferentes, rodean al lector de una atmósfera impregnada de lo básico de su poesía: el tono líricoelegíaco, la presencia ilimitada de la mujer amada, y el anhelo de una vida espiritual superior.

Bellísimos sonetos son éstos. La sutileza de su pensamiento que envuelve un sentir cálido y apasionado, encuentra salida en expresiones exactas y claras. Un ejemplo inmediato de lo que podemos llamar su técnica (técnica de correlaciones y repeticiones) se puede 
citar con relación a estos sonetos, en los que la idea de blancura y pureza es el elemento primordial. La repetición de la misma idea, en diferentes términos, refuerza a medida que el número aumenta, la subyugante seducción de este pensamiento fijo en la mente del autor, y que acaba por transmitirse al lector, en fortísima comunión espiritual. Formado con capas tenues, levísimas, el conjunto es poderoso y dominante. Bien quisiéramos, por ejemplo, poder citar aquí diferentes versos, para poder demostrar el modo en que el autor nos transmite una extraña sensación de blancura, de pureza, y de luminosidad. Pero como la falta de espacio no nos lo permite, tenemos que limitarnos a copiar solamente un poema, para dar una idea aproximada de lo que acabamos de decir:

\section{I I I}

Llevo de ti la sensación más pura de las cosas lejanas nunca usadas, de las olas del mar jamás tocadas, de la estrella la mística blancura.

No sé si es el deseo o la ternura pero llevo en mis ojos retratadas la auroral suavidad de tus miradas y el primer resplandor de tu hermosura.

Todo lo que en el aire se eterniza:

la dureza del sueño, la sonrisa hecha cristal, la luz de la mañana,

el vuelo do los pájaros marinos, la lejana presencia de los pinos en la humareda azul de la montaña. 
Pero estos versos nos dan solamente una faceta de las muchas que forman este conjunto de blancura y nítida limpidez. Esta impresión se refuerza cada vez más al transcurrir la lectura de los dieciocho sonetos.

Transmisión de luz, en que hasta la sombra es "luminosa", poemas elevados, de íntima ternura, poemas casi místicos en su sentir, tono elegíaco, la soledad (soledad-ausencia-soledad) le inspiran estos versos clarísimos:

Aire que no respiras y que siento

hay una angustia fría en toda cosa

su suprema expresión encontrándose en aquel delicado soneto que empieza: "Lejos de ti ni a la belleza aspiro".

Los símbolos son de una exactitud y una plasticidad admirables:

Es una lenta miel no derretida que ni poder ni vanidad presume

Es opulenta miel que está vertida en tu piel de naranja y se resume...

y la miel de tu boca se convierte en su lento fuir de hilos dorados en el símbolo dulce de la mucrte.

y en la expresión del sufrimiento puro:

es estar junto a ti $y$ en el olvido es estar a tu lado y siempre ausente;

es un lento suicidio sin sentido es morir sin morir, un pervertido placer de desangrarse dulcemente. 
El lector se siente compenetrado por la gracia, permanente en los oídos, de "Tu gracia mejor", el misterio expresado en "Mujer lejana", y la sencilla belleza de "Adiós": dolor punzante, íntimo grito que nos traspasa el pecho con su simple decir:

Dolor de decirte adiós

con la sonrisa en la boca

$y$ en el pecho tres puñales.

Dolor de decirte adiós

con la angustia de sentirte

ya lejana en la presencia.

las nostalgias, las saudades, los recuerdos, nos anegan el alma de íntimos efluvios, de intensas y recónditas emociones, de inexplicables tristezas, de recuerdos semiolvidados en el tiempo y la distancia:

Es la voz de la madre o el olor del membrillo, la canción del jilguero o el sabor del huesillo, el vaho de la ticra maternal y fecunda.

Mientras que "Tendrás en la alta noche" es un presentimiento de tristezas y amarguras futuras en los besos y las caricias presentes. El tiempo de estos versos sirve para aumentar esta sensación de tristeza y angustia infinitas. Poema fatalista filosófico y augural, es bellísimo en su simplicidad y en su visión del futuro:

Lo sabrás esa noche

esa noche de sombras

en que llegue a tu rostro un viento helado

de mar que ya no existe, y en que sientas

un aroma de lilas en los dedos

y una visión de luna en las pupilas

$y$ en que pase a través de tu garganta

el sollozo sin fin de mi recuerdo. 
La presencia todo abarcadora del recuerdo de la mujer amada sobre el alma sensitiva del poeta se torna palabras en "Te veo en el paisaje", en que tan vívidamente está expresado cómo la persona amada que llevamos dentro de nosotros se manifiesta en todo objeto exterior, especialmente en el paisaje:

\author{
No necesito verte \\ no necesito hablarte \\ murmullo de aire sobre arena y agua.
}

Al mismo tiempo la apasionada presencia de la mujer encuentra amplia expresión en rasgos limpios y claros:

\title{
Déjame
}

tu cucrpo largo y frío

como un lirio desnudo;

déjame

tu lenta palabra

tan llena de neblinas $y$ de angustias.

Sus símbolos son fuertes y claros, exactas imágenes. En "Ha muerto lejos" nos sacuden sus versos:

Ha muerto dice el sol

ha muerto dice el viento.

En un caballo negro

pasa loco el recuerdo.

El día gris se oculta

como muchacho ciego...

Su poema "Nueva York" tiene la fuerza de aquel otro poema, inspirado en el mismo tema. Es aquí donde su técnica de las correlaciones se muestra más claramente y con mayor fuerza. El poema es una especie de cantata a cuatro voces, en que la primera la cons- 
tituiría el tema de Nueva York; la segunda, el del poeta; la tercera, el de la tierra lejana; y la cuarta, el de la tierra futura. La falta de espacio no nos permite tratar esto de un modo más extenso, solamente nos limitaremos a mencionar cómo estos temas se combinan y se mezclan. Pero a través de todo el poema reaparece uno de ellos momentáneamente más fuerte que los demás.

Alli en tus calles yo, joven sonámbulo

dice el poeta, que

artesano del sueño de puntudas rodillas, con una palidez de mil noches de abstinencia y deseo...

de repente, cual otro Dante, se encuentra en una “... densa floresta de visiones..." Es esta una floresta en que a su "... sombra duermen los cementarios abrasados..." y en que "....con humildad y silencio de perro de hombre muerto..." el joven poeta

temeroso de agotar la copa púrpura de tus bares en una doliente continuidad de pobrezas provincianas

pasea su angustia, recordando aquella tierra suya, tan suya, y su familia, y pensando constantemente en las palabras amadas que habían de llegar:

cartas de voces calientes, de amor, de solaridad, de ternura, prisioneras en las heladas bodegas de los buques.

El sentimiento de la soledad lo domina, soledad que sólo se ve mitigada por aquella maravilla: las cartas familiares. Gracias a ellas el nostálgico soñador

podia desafiar a las muchedumbres en sus conchas

y ellas eran 
mis muletas de hombre mutilado en ninguna guerra... ...mis alas de canario caído en una hoguera...

El tema de la ciudad reaparece. Esta le atrae y le fascina:

. de la espina salieron las puntas de tus torres, de los colmenares los cubos cálidos de tus arañacielos; con la ciencia elemental de la hormiga movilizas tus siete

[millones en las mañanas frescas de melón y en los crepúsculos de [naranja...

mariposas gigantes pasan rozando las azoteas atraidas por las orquídeas que florecen a destiempo

y siente el soplo cálido de la ciudad y de sus mujeres:

en el andar de tus mujeres hay rápidos enlaces de putpos,

y pasa las noches

...mordiendo en mis vigilias visiones y en mis manos deshojando camelias de mujeres vistas en los subways

Toda una historia está escrita en estas líneas. Una descripción completa de juventud, ausencia, horror de la gran urbe.

$Y$ vi que la vida de tu gente era una muerte constante $y$ que las voces del amor eran como roce de escamas $y$ que los espejos deformaban los rostros de amigos y parientes $y$ que las mujeres iban vestidas de plata $y$ de mercurio

Y por eso mi recuerdo de ti estará junto a un revólver al lado de un dolor agudo en los dedos y en los ojos. 
Pero el horror de la ciudad inmensa y extranjera, unido a la nostalgia por la tierra amante y amiga le obligan a alejarse de ésa

...pradera interminable y negra...

con la alegría sencilla de los jilgueros cautivos

para ganar el espacio y la libertad en una tierra nueva con la alegría de pájaros que

. recobran el vuelo en la hoja del sauce y en el olmo.

Hemos mencionado solamente algunos de los muchos elementos que forman este libro. No hemos tocado siquiera, por ejemplo, aquellos poemas de fondo más filosófico o de contenido conceptual más profundo. Estas líneas tratan, pues, solamente de algunas partes de un mundo tan completo.-Mireya Jaimes-Freyre.

Columbia University, Nueva York.

"La Era de Trujillo", de Jesús de Galíndez. Un estudio caşústico de dictadura hispanoamericana. Editorial del Pacífico S. A. Cuarta edición. Santiago de Chile, 1956. 452 páginas.

Un largo debate periodístico - una crónica policial, una crónica política- preparó al lector para recibir este libro. Una tragedia oscura - la desaparición del autor, probablemente muerto- engendró la simpatía que exige el libro.

La Era de Trujillo, del profesor vasco Jesús de Galíndez, esperada con expectación parece defraudar a gran número de lectores. Sin embargo, nos parece que es el libro que nos hacía falta.

Si esta investigación hubiera sido un ensayo de hermoso estilo, lleno de ingeniosas imágenes y por demás agudo, alguien hubiera dicho: es pura literatura. Aquí no cabe el dicho. 